\title{
External Debt Management in Pakistan: A Market-Based Assessment
}

\section{Jamshed Y. Uppal*}

\begin{abstract}
Economists typically use multiple indicators to assess the burden of external debt, such as the ratios of the stock of debt to exports and to gross national product, and the ratios of debt service to exports and to government revenue. As opposed to those methodologies, this article examines the Pakistan's external debt position using a market based approach which analyzes the marginal costs of external debt as indicated by the yields on the country's Eurobonds and the spreads on the Credit Default Swaps (CDS) traded in the international markets. The results show a sharp decline in the yields on the Pakistani Eurobonds from their peak reached during the global financial crisis (GFC) period and this decline was largely driven by quantitative easing and the resultant low interest rates in the international debt markets. Also, the continued decline in the yields in the more recent period, 2013-2017, was due to strengthening of the county's borrowing capacity over the period. The analysis also shows that Pakistani yields seem to be converging to yields for other Asian countries, even though that the yield-spreads between Pakistan and others countries are still substantial. In conclusion the decrease in bond yields and CDS spreads may signal that the country's external debt is currently at sustainable levels.
\end{abstract}

Keywords: External debt, Debt management, economic growth, Pakistan.

JEL classification: H63.

\section{Introduction}

The sound management of external debt remains a lingering concern in Pakistan, having garnered renewed interest in the wake of the economy's lackluster performance in 2008. Severe internal and external pressures resulted in a sharp increase in Pakistan's external debt, compelling it to request a stand-by-arrangement from the International Monetary Fund

\footnotetext{
* Associate Professor of Finance, Busch School of Business and Economics, Catholic University of America, Washington, DC, USA.
} 
(2016). The rapid increase in external debt over the last decade has prompted numerous reports questioning its sustainability and possible adverse impact on the country's economic stability and growth (see, for example, Khan, 2016; Abbasi, 2016; Bokhari, 2016; Tirmizi \& Masooma, 2017).

Economists use several macroeconomic indicators to assess the burden of external debt, such as the ratios of the stock of debt to exports and to gross national product, and the ratios of debt service to exports and to government revenue. Although these indicators are widely accepted as measures of a country's indebtedness, they are not well demarcated in terms of signaling what constitutes an unacceptable level of debt. For example, the World Bank follows a set of parameters used to categorize countries as "moderately" or "severely" indebted. Since countries with higher export growth rates, for example, can support higher external debt than those with lower export growth rates, it is only possible to lay down broad guidelines governing external debt sustainability (Loser, 2004). A failure to determine appropriate levels of sustainable external debt is a key reason that external debt-related problems have persisted for many developing countries (Muhanji \& Ojah, 2011).

Most academic studies focus on conventional debt measures of public debt sustainability (see, for example, Di Bella, 2008; Goktas \& Hepsag, 2015). The literature also includes early-warning systems for sovereign debt crises, developed using key economic indicators: see, for example, Lang (2013); Fuertes and Kalotychou (2007); Lewis (2011); Manasse, Roubini and Schimmelpfennig (2003); Tian, Li and Lu (2012); Babecký et al. (2012). Similarly, studies on Pakistan's external indebtedness are based on conventional measures: see, for example, Ahmad (2011); Iqbal et al. (2015); Mahmood, Arby and Sherazi (2014); Waheed (2006). Several studies on sovereign debt, however, use market-based indicators such as sovereign bond yield. Most of these relate bond yields to the conventional measures of indebtedness derived from the national accounts. Afonso and Rault (2010), for example, show that markets consider budgetary and external imbalances and inflation to be relevant determinants of sovereign yield.

Csonto and Ivaschenko (2013) analyze the relationship between global and country-specific factors and emerging market debt spreads. Poghosyan (2012) and Rowland and Torres (2004) study the determinants of sovereign bond yields. Bellas, Papaioannou and Petrova (2010) find that, in the long run, fundamental indicators are significant determinants of emerging market sovereign bond spreads, while in the short run, financial volatility is a more important determinant. Ciarlone and Trebeschi (2005) 
have developed an early-warning system for debt crises that integrates the analysis based on macroeconomic variables with an approach based on risky market instruments. Increasingly, the literature has looked at the credit default swap (CDS) spread as an indicator of the debt market perceptions of sovereign creditworthiness (see Atrissi \& Mezher, 2011).

Debt market indicators have assumed greater relevance in recent decades, with the remarkable increase in private capital flows to developing countries through the issuance of international bonds. There has been a significant rise in new bond issuance by "frontier markets", including firsttime issuers in the international sovereign debt market, particularly subSaharan African countries. Gurría (2014) and Arslanalp and Tsuda (2014) estimate that about half a trillion dollars in foreign flows went into emerging market government debt during 2010-12 - most of it from foreign asset managers. They also show how investor-based data can be used to assess countries' sensitivity to external funding shocks and the rebalancing of foreign investors' portfolios.

This paper examines Pakistan's external debt position using a market-based approach. Instead of using conventional measures of external indebtedness such as the debt-to-GDP ratio, we examine the marginal cost of external debt as indicated by the yields on the country's Eurobonds and the spreads on the CDSs traded in international markets. A sharp increase in bond yields or in CDS spreads would signal that the country's external debt is approaching unsustainable levels. The advantage of this approach is that the data needed to evaluate debt sustainability is more frequent (daily) than that used in conventional ratio analyses. National economic data may only be available on a quarterly basis, while the country's credit ratings change infrequently. Bond yields and CDS data is market-generated and reflects the assessment of numerous international market participants, while economic data is generated by government agencies and may be susceptible to window dressing.

The paper is organized as follows. Section 2 reviews the country's external debt, using a conventional ratio. Section 3 provides an assessment of external debt employing market-based indicators. Section 4 presents an econometric study of the linkages between the yields on debt and international yields. Section 5 presents a discussion of the results. Section 6 presents the study's conclusions and policy implications. 


\section{Conventional Assessments of External Debt}

The use of conventional assessment tools is subject to many interpretations, as evident from recent discussions on Pakistan's external debt. While many economic journalists and academics have raised concerns over the country's growing external debt, the finance minister paints a very different picture.

A prominent critic is Khan (2016) who notes that, "apart from the direct consequences for national security, rising debt is also a threat to macroeconomic stability and hence to growth, employment generation and poverty alleviation." He adds: "The recent pace of accumulation of debt suggests that, if [it] remain[s] unchecked, Pakistan's public debt in general and external debt in particular... [will] reach an unsustainable level in the next five years." Khan's arguments are based on analyses using conventional ratios and on projections of the country's GDP and exports. He focuses on the burden of total debt indicators, such as external debt and liabilities (EDL) as a percentage of exports, EDL as a percentage of foreign exchange (FX) earnings (including exports, remittances and foreign investment) and the EDL growth rate, as shown in Figures 1 and 2.

Figure 1: Pakistan, debt ratios, 1999-2015

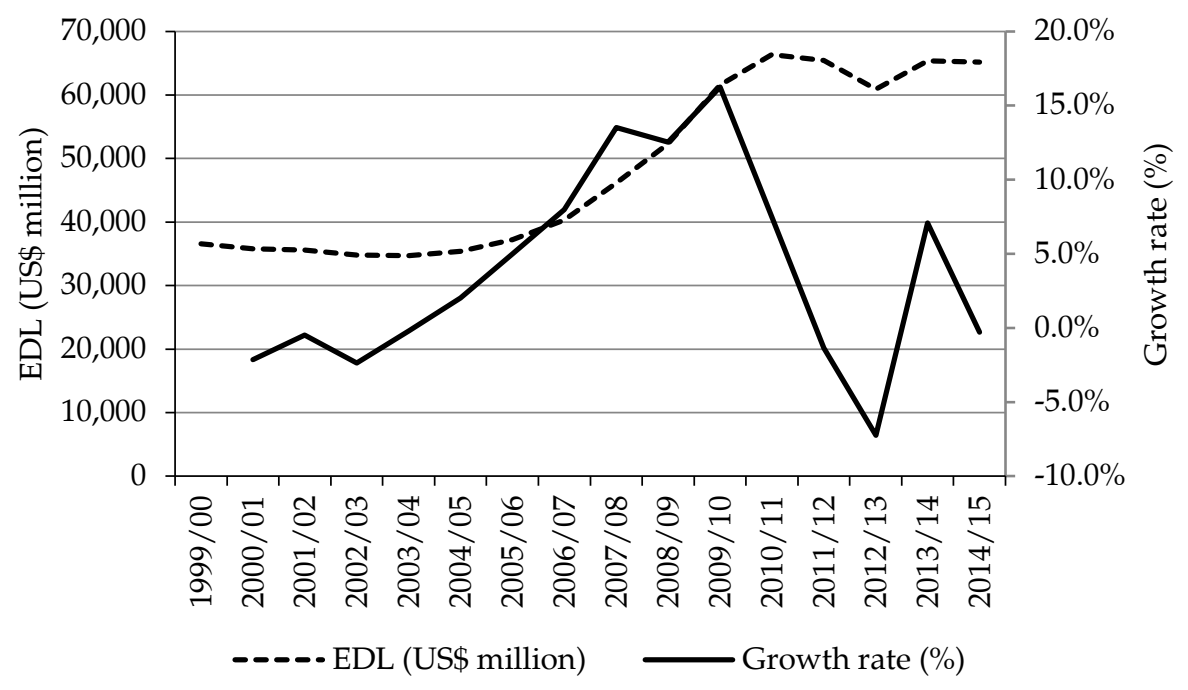


Figure 2: Pakistan, external debt and growth, 1999-2015

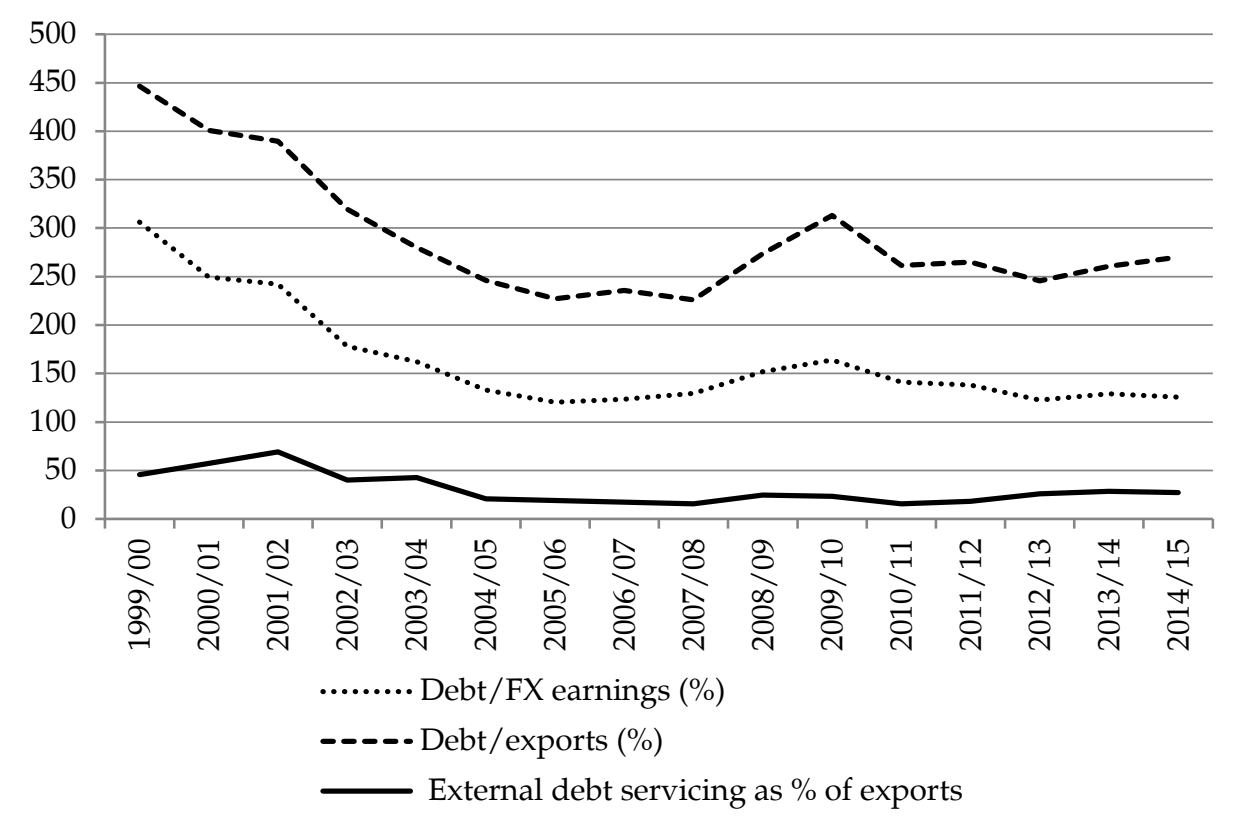

In the absence of a hard optimum or cutoff debt burden ratio, such data is prone to varied interpretations and prognoses by judiciously selecting periods and statistical series. As Figures 1 and 2 show, the recent trend (since 2011) in the debt ratio is not all that alarming. For example, the average compound rate of growth in EDL for the period 1990-2015 is 3.85 percent. However, for the subperiod 1999-2006, it is 0.30 percent; for the period 2006-11, it is 11.56 percent and for the more recent period 2012-15, it is -0.45 percent.

Khan's (2016) assessment of the country's debt situation relies more on projections based on his assumptions concerning the growth in GDP and exports and on fresh liabilities likely to be incurred under the ChinaPakistan Economic Corridor (CPEC) projects. Again, there is room for both pessimism as well as optimism in making these projections. The federal finance minister's recent comment that "economic indicators are always open to interpretation and debate," builds on two assumptions. ${ }^{1}$ First, he considers only 'public debt' and excludes private debt, that is, the FX borrowings of banks, state-owned enterprises and the nonfinancial private sector. The comparative numbers are given in Table 1 .

\footnotetext{
${ }^{1}$ https:/ / www.thenews.com.pk/print/183227-Pakistans-Debt-Putting-the-record-straight
} 
Table 1: External debt, 2013 and 2016

\begin{tabular}{lccc}
\hline & $\begin{array}{c}\mathbf{2 0 1 3} \\
\text { US\$ billion }\end{array}$ & $\begin{array}{c}\text { 2016 } \\
\text { US\$ billion }\end{array}$ & $\begin{array}{c}\text { Growth rate } \\
\text { Percent }\end{array}$ \\
\hline Public external debt & 48.1 & 57.7 & 6.25 \\
EDL & 60.9 & 73.0 & 6.23 \\
\hline
\end{tabular}

As the table shows, the compound annual growth rate over the last three years is not much different, although the larger debt figures do seem ominous. Second, the minister takes a "pragmatic and realistic" approach to measuring "net external indebtedness", that is, external public debt less official FX reserves held by the State Bank of Pakistan. Comparing the last three years' external debt position gives us the following picture (Table 2):

Table 2: Reduction in indebtedness

\begin{tabular}{lcc}
\hline & $\begin{array}{c}\text { June 2013 } \\
\text { US\$ billion }\end{array}$ & $\begin{array}{c}\text { June 2016 } \\
\text { US\$ billion }\end{array}$ \\
\hline External public debt & 48.10 & 57.70 \\
SBP FX reserves & $4.00^{*}$ & 18.10 \\
Net external public debt & 44.10 & 39.60 \\
Reduction in indebtedness & & 4.50 \\
\hline
\end{tabular}

Note: * does not include US\$2 billion of short-term FX swap.

Based on this, the minister shows that Pakistan's indebtedness had improved by US $\$ 4.5$ billion by the end of June 2016 compared to June 2013. He may have a valid point, as FX reserves can be drawn to pay maturing debts. However, a sudden drawdown of reserves would signal financial distress, rattling the FX and credit markets and possibly triggering an economic crisis.

Some economists have questioned the wisdom of building up reserves by incurring external loans. Arguably, FX reserves carry economic benefits: they (i) provide a cushion to absorb any shocks to the country's current and capital accounts, (ii) help tone down FX rate volatility and thus FX risk, (iii) help bring down the cost of borrowing by improving credit ratings, and (iv) moderate the cost of imports and credit insurance as the country's creditworthiness improves from the perspective of foreign suppliers. However, the cost of maintaining FX reserves must be balanced 
against the benefits. ${ }^{2}$ Pakistan's FX reserves, equivalent to about five months of exports, are lower relative to those of comparator countries.

The discussion above shows that there is considerable room to interpret economic data and it is easy to disagree as to prudent levels of debt. Much of this disagreement arises because there are no universally accepted limits to debt levels and economists differ widely as to the future course of the economy. Finance theory suggests that, as a country moves closer to its debt capacity, its marginal cost of borrowing will increase sharply (see Figure 3). Therefore, this paper gauges Pakistan's external debt position using an alternative approach. Instead of using conventional measures of external indebtedness such as the debt-to-GDP ratio, we examine the marginal cost of external debt as indicated by the yields on the country's Eurobonds and the CDS spreads being traded in international markets. As noted above, a sharp increase in bond yields or CDS rates would signal that the country's external debt is reaching unsustainable levels.

\section{Figure 3: Cost of debt and debt capacity}

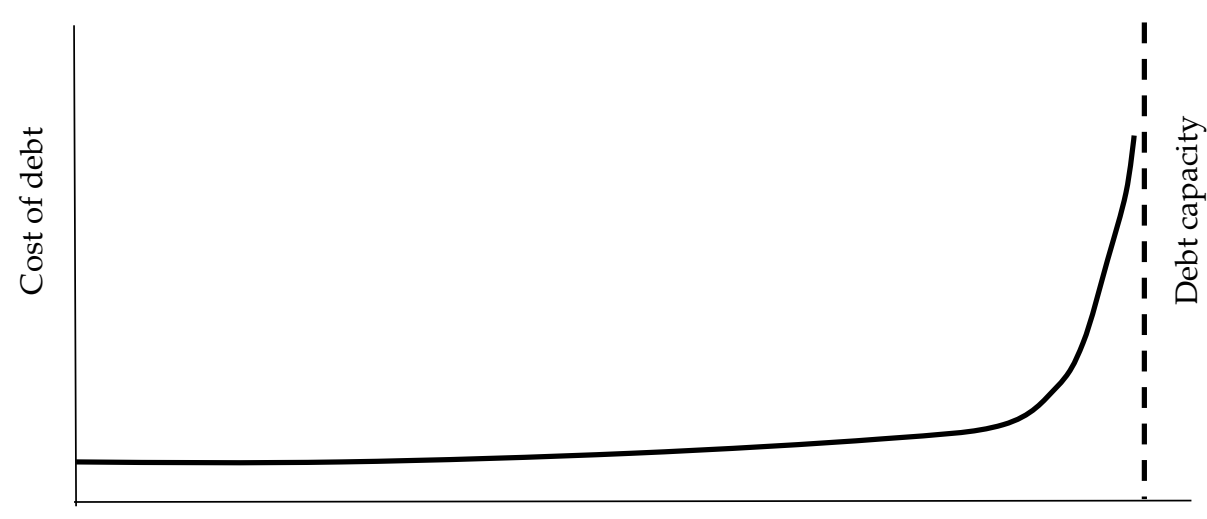

Indebtedness

\section{Market-Based Assessments of External Debt}

As with other developing countries, Pakistan has tapped into other financial markets to raise sovereign debt, such as the recent issue of US $\$ 1$ billion in sukuk bonds at a coupon rate of 5.5 percent. As of the beginning of 2017, the total volume of Eurobonds and sukuk issued by the Government

\footnotetext{
${ }^{2}$ For example, cost of maintaining additional reserves of \$14 billion at a marginal rate of 5\% percent ( $\$ 700$ million) will be roughly offset if there is 1 percent decrease in the borrowing cost ( $\$ 730$ million) over the total EDL of $\$ 73$ billion.
} 
of Pakistan (and its special purpose entities, SPVs) was worth US\$5.5 billion or about 9.5 percent of the public external debt. The main features of these internationally issued securities are summarized in Table A1 in the Appendix. The market price information on the Eurobonds/sukuk allows us to compute the yield to maturity on these securities. In addition, CDS are traded against sovereign and sovereign-guaranteed securities. We use this information as follow:

- The yield to maturity is computed daily, based on the quoted prices of the securities (obtained from Datastream, Thomson Reuters), their promised cash flows (periodic coupon and principal payments) and time to maturity. A yield curve is constructed for each day, based on the outstanding maturities of each bond. The daily yield curves are then used to interpolate the yield for one-year, five-year and ten-year maturity bonds, using a polynomial curve fitting. This method, illustrated in Figure 4, is similar to that used by the US Treasury to report constant-maturity yields for various tenures. We obtain a series of one-year, five-year and ten-year constant-maturity yields, which are then compared with the US Treasury constant-maturity yields.

\section{Figure 4: Determining constant maturity yield}

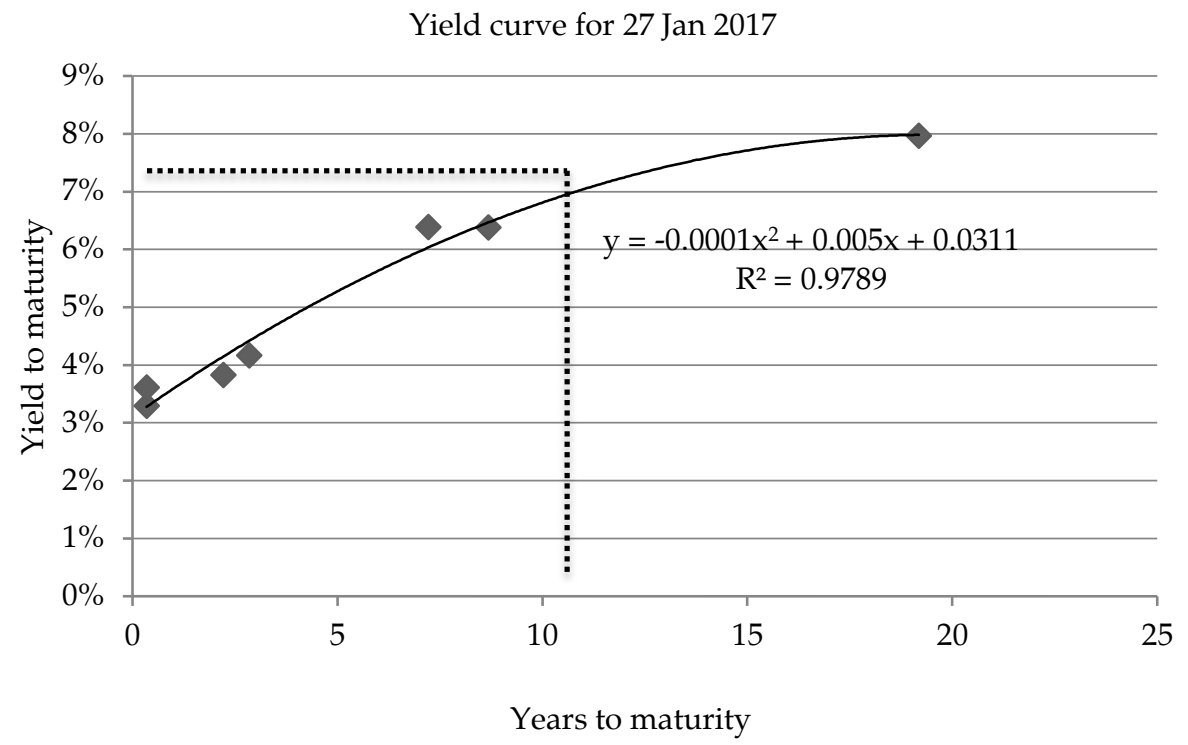

- JP Morgan emerging market bond indices (EMBIs) are used to track bonds in emerging markets (as constructed by JP Morgan). We use EMBIs for Asia, Pakistan and selected countries for comparison and empirical analysis as explained in the next section. 
- Country credit ratings or Pakistan's sovereign debt ratings are obtained from two major agencies: Standard and Poor's and Moody's. We convert their letter ratings to numerical values to create a rating score for comparison purposes. ${ }^{3}$

- $C D S$ denote contracts designed to transfer the credit exposure of fixedincome products between two or more parties. The buyer of the swap agrees to make payments to the seller until a certain maturity date. In return, the seller agrees that, should the debt issuer default or experience a credit event, the seller will pay the buyer the security's premium as well as all interest payments that would have been paid between the event time and the security's maturity date.

An International Monetary Fund (2013) study finds that sovereign CDS are generally reliable market indicators of sovereign credit risk reflecting the same economic fundamentals and other market factors. However, CDS markets appear to incorporate information faster than bond markets in periods of stress. CDS spreads, therefore, reflect the default probability of the underlying security and provide insurance to the security holder against default. The CDS spreads were obtained from Datastream and are used in the empirical exercise in this study.

Figure 5 plots the five-year constant-maturity yields, the CDS spreads (left axis) and the sovereign debt rating scores (right axis) for Pakistan from November 2004 to January 2017. We can see that the yields on Pakistani securities are positively related to the CDS spreads, which in turn reflect the country's default risk. On the other hand, the credit ratings are inversely related to the yields. It is noteworthy that the yields spiked sharply to over 25 percent during the global financial crisis (GFC) period 2007-09, along with a sharp increase in CDS spreads, while credit ratings dropped precipitously. Another rise in the yields occurred in 2011, but this was not accompanied by an increase in the CDS spreads. This likely reflects tighter international financial markets rather than the country's creditworthiness, as also reflected by the steady credit ratings. Post-GFC, we see a sharp drop in Pakistani yields, followed by an upward trend during 2009-11. There has been, however, a general downward trend in the yields since January 2012, accompanied by an improvement in credit ratings and a decrease in the CDS spreads.

\footnotetext{
${ }^{3}$ Standard \& Poor's ratings are issued as letter grades from AAA to D. Moody's follows a similar system from AAA to D. Standard \& Poor's BBB rating implies "adequate financial performance, but may be adversely affected by economic downturn." The "BBB-" rating is the lowest grade that will likely be considered by investors. These letter grades are further classified by the debtor's "outlook". We assign a score of 12 to the "BBB-" rating.
} 
Figure 5: Pakistan, sovereign ratings, CDS spreads and yields

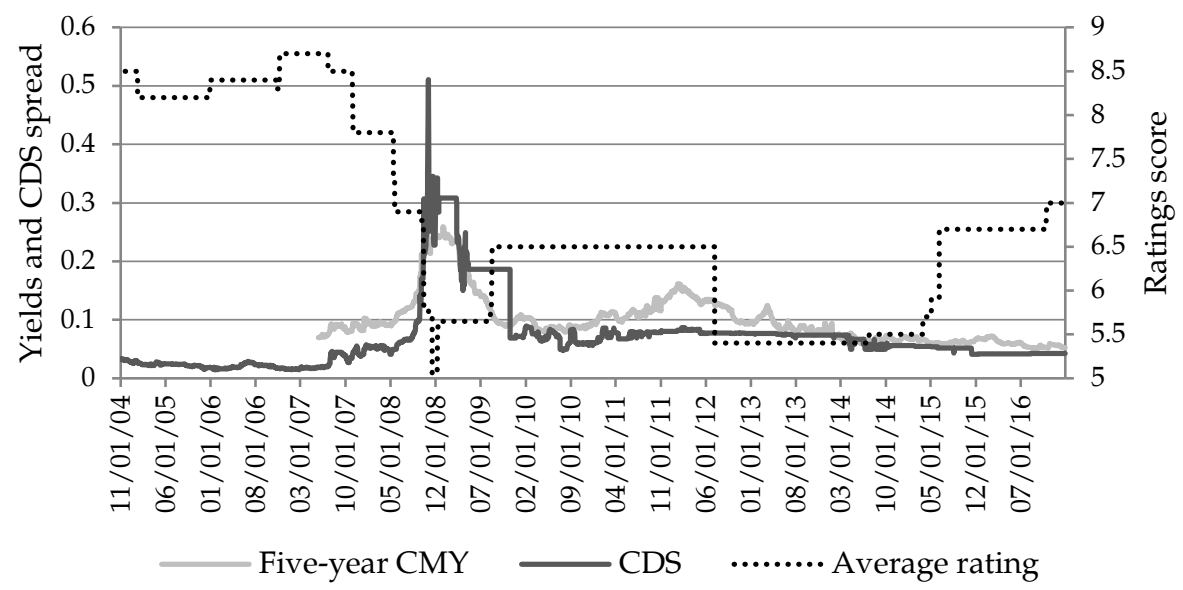

A key factor that affects yields and the cost of borrowing is sovereign ratings. Figure 6 compares Pakistan's ratings with those of India, showing that the latter's sovereign debt is rated far above that of Pakistan. India's ratings have been consistently classified as investment-grade (above BBB-) since 2007, while Pakistan's have fallen below CCC - indicative of a "vulnerable financial condition" - for some periods. In recent years, however, Pakistan's ratings have improved. The latest upgrade in October 2016 was by Standard \& Poor's to B with a "stable" outlook. Despite the recent uptick, Pakistan's ratings are still about 5.5 notches below those of India (Moody's Baa3/positive).

Figure 6: Sovereign ratings, Pakistan versus India

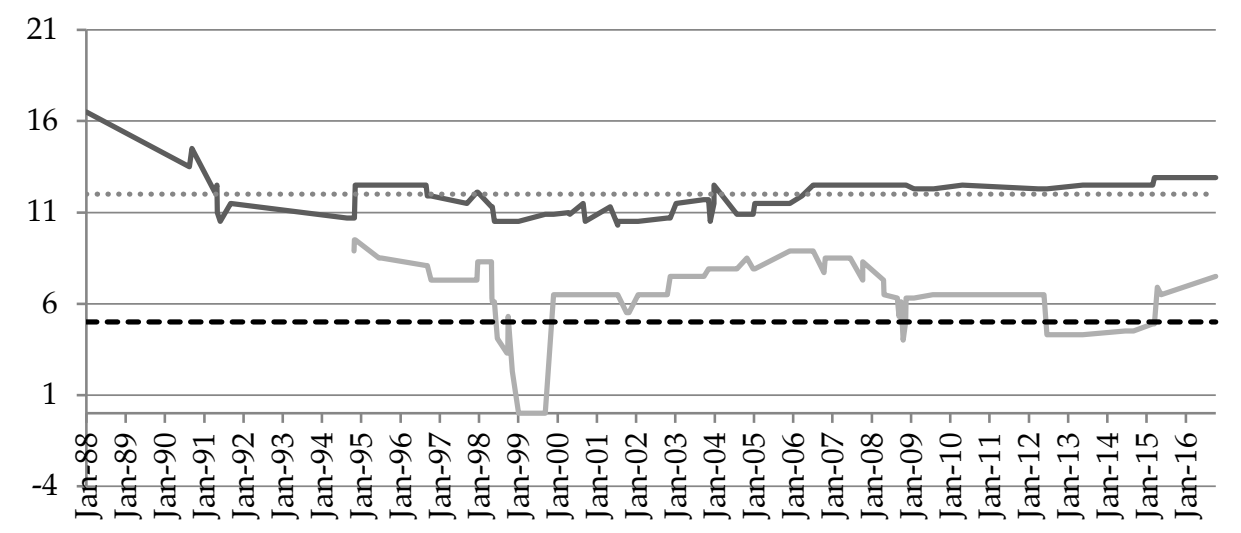


For comparison purposes, we plot the EMBI yields for Pakistan, the Asia group averages and yields for selected countries in Figure 7. We can see that the EMBI yields for Pakistan declined from a peak in 2001 and remained within the range of yields for the peer group until about the onset of the GFC. The yields seem to rise disproportionately during the GFC period. A disproportionate response also occurs in 2010/11, when the Pakistani yields shoot up in response to a somewhat mild increase in the other series. Since the beginning of 2012, there has been a continuing decline in the yields, which more recently has brought them closer to the yields for the peer group.

Figure 7: JPM EMBI yield-to-maturity

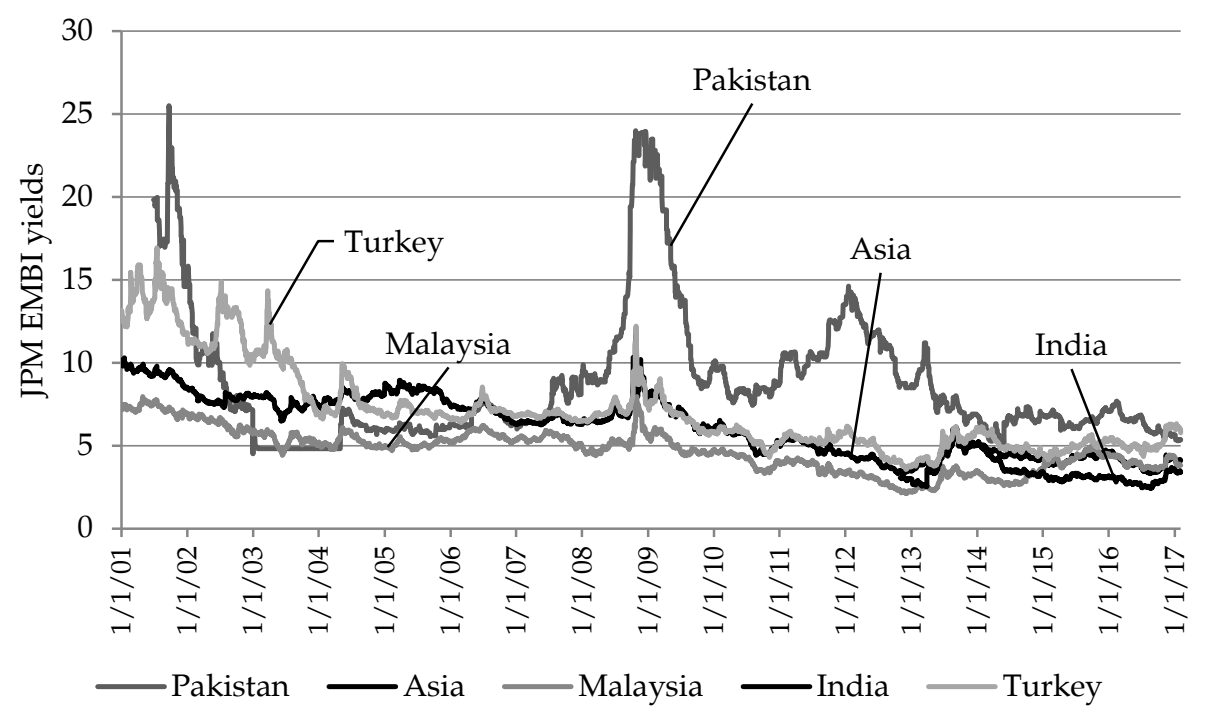

Although the Pakistani yields seem to be converging onto the yields for other Asian countries, we note that the yield spread between Pakistan and the other countries is still substantial, as Figure 8 shows. We note a sharp decline in the yield spreads over their peak in March 2013, which continues until about May 2014. Then there is a jump in the yields, followed by a period in which they fluctuate within a range: about 2.5 percent over the Asian average and 3.5 percent over the Indian yields. The more recent period (since January 2016) has seen a downward trend in the spreads, which were close to their historical lows of just over 1 and 2 percent (the minimum was about 0.5 percent for a brief period, February-March 2014). 
Figure 8: JPM EMBI yield spread

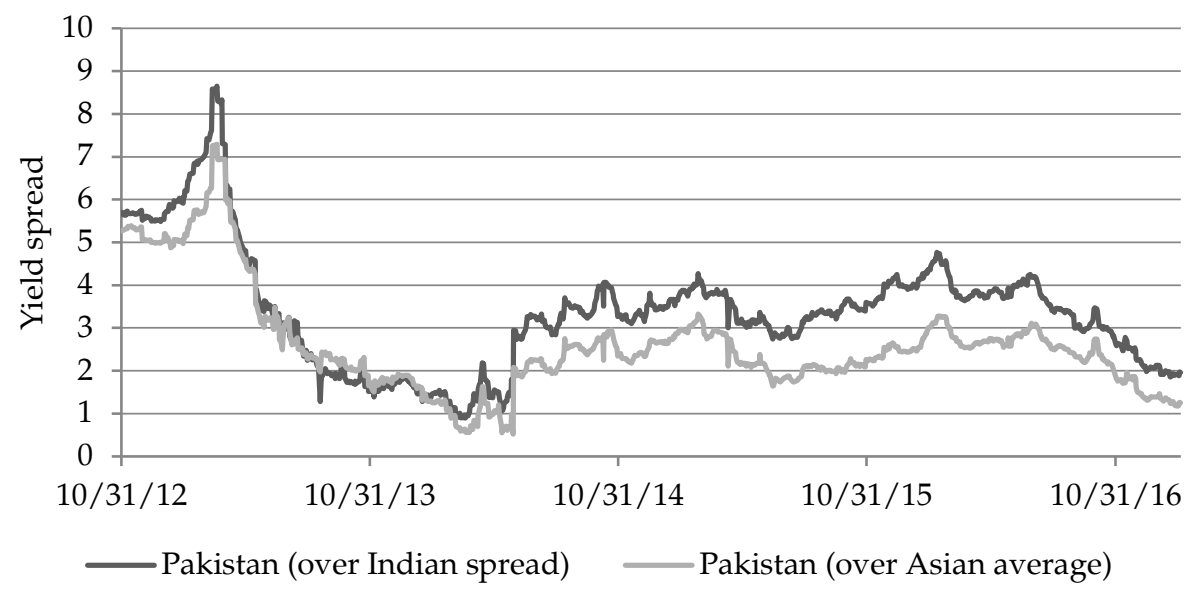

Next, Figure 9 shows the yield maturity structure for Pakistani Eurobonds/sukuk estimated at the beginning of each year for the period 2012-17. As the figure shows, the yields have declined for all maturities over the period. This reinforces the reading of the trend in yields over recent periods, that is, a continuing decline in yields and, therefore, in the marginal cost of external debt to the country.

Figure 9: Yield curves over time

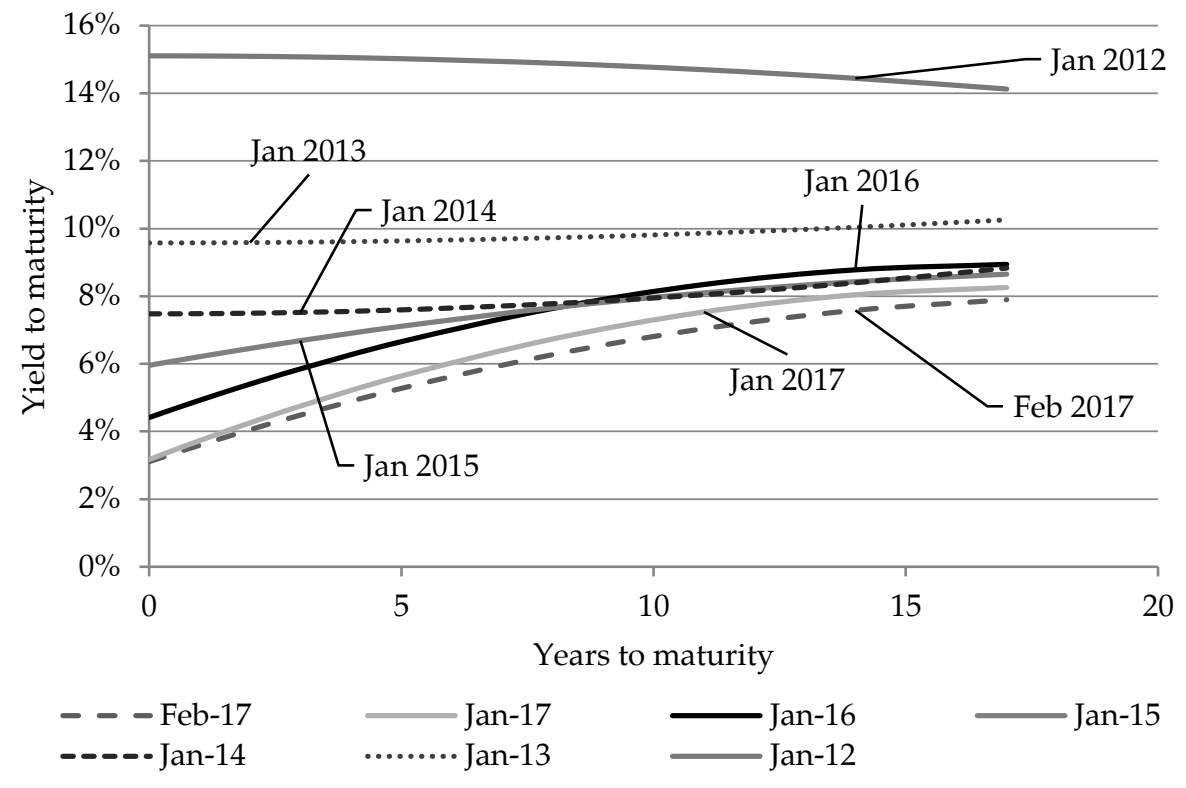


Here, the yield-to-maturity represents a rate of return for the investor in the bonds at current prices. It also represents the cost at margin for the issuer, although to obtain an estimate of the effective cost to the borrower, we need to factor in the flotation costs associated with each issue. ${ }^{4}$ Thus, a spread of 2 percent would translate into approximately US\$20 million for a US $\$ 1$ billion bond in terms of the annual financial cost advantage in favor of one's competitor. This is still a far better position than having a spread of 7 or 8.5 percent, which would translate into US\$70-85 million a year. Here, we are considering the yields on sovereign debt, which reflect the cost of borrowing for the private sector (including the cost of financing trade) and are typically linked to the country's sovereign yields. Thus, any decrease in sovereign yields will also bring down financial costs for the private sector, providing considerable relief, especially to the exports sector.

It is not possible to determine precisely which factors are responsible for the decline in yields, part of which may be due to improvements in domestic factors such as the economic and political environment or a lower incidence of terrorism. However, part of this decline may also be attributable to international supply factors such as easier interest rate regimes, a decline in crude oil prices and smaller risk premiums required by international investors. In the next section, we attempt to empirically separate the impact of domestic factors from that of international factors to better understand the cost of Eurobonds for Pakistan.

\section{Empirical Tests for Yields}

We examine the behavior of the yield on Pakistani bonds (JPM EMBI Pakistan) over time as affected by international and Asian yields. US treasury yields (constant five-year maturity) are used as a proxy for the former, while JPM EMBI Asia yields represent the latter. The US interest rate and macroeconomic fundamentals play a significant role in determining bond spreads in emerging economies (see, for example, Min et al., 2003). We also include the spreads on the Pakistan CDS (five-year). The long-term relationship is studied using two empirical models: (i) a four-variable vector error correction (VEC)/error correction model (ECM) to capture the long-term relationship between Pakistani yields and the three explanatory variables and (ii) multivariate GARCH models to examine the yields over time.

\footnotetext{
4 A 2 percent flotation (issuance) cost will add 26 basis points on a 5 percent, five-year bond to the cost of debt for the borrower.
} 


\subsection{Cointegration Analysis}

The ECM is a useful model for detecting long-term relationships between time-series variables (including many macroeconomic variables) that may be nonstationary (Engle \& Granger, 1987). In this case, we use an $\mathrm{ECM}$ to examine the long-term relationship between the yields series and CDS spreads. The VEC representation of the model is a restricted VAR with the cointegration restrictions built into the specifications. The endogenous variables are restricted in the VEC representation so that they converge on their cointegrating relationships in the long run. At the same time, the model allows a wide range of short-run deviations from the long-run equilibrium, which are corrected through a series of partial short-run adjustments. Johansen's method is used to test the restrictions imposed by cointegration on the unrestricted VAR model.

We hypothesize a simple long-term relationship between the Pakistani bond index yields and the explanatory variables, with an intercept but without a trend, with one cointegrating equation and two lagged difference terms. Since the fundamental structure of the expected yield is expressed in finance as the risk-free rate plus premiums, the yields on the US treasuries are included to represent the risk-free rate. The Asian index is expected to capture a base risky yield and the CDS spreads are expected to reflect country risk. The ECM equations are as follows: ${ }^{5}$

$$
\begin{aligned}
& \Delta P K Y_{t}=\alpha_{1}+\gamma_{1}\left(E C T_{t}\right)+\delta_{1,1} \Delta P K Y_{t-1}+\delta_{1,2} \Delta P K Y_{t-2}+\delta_{1,3} \Delta A S Y_{t-1}+ \\
& \delta_{1,4} \Delta A S Y_{t-2}+\delta_{1,5} \Delta U T Y_{t-1}+\delta_{1,6} \Delta U T Y_{t-2}+\delta_{1,7} \Delta C D S_{t-1}+\delta_{1,8} \Delta C D S_{t-2}+ \\
& \varepsilon_{1, t} \\
& \Delta A S Y_{t}=\alpha_{1}+\gamma_{2}\left(E C T_{t}\right)+\delta_{2,1} \Delta P K Y_{t-1}+\delta_{2,2} \Delta P K Y_{t-2}+\delta_{2,3} \Delta A S Y_{t-1}+ \\
& \delta_{2,4} \Delta A S Y_{t-2}+\delta_{2,5} \Delta U T Y_{t-1}+\delta_{2,6} \Delta U T Y_{t-2}+\delta_{2,7} \Delta C D S_{t-1}+\delta_{2,8} \Delta C D S_{t-2}+ \\
& \varepsilon_{1, t} \\
& \Delta U T Y_{t}=\alpha_{1}+\gamma_{3}\left(E C T_{t}\right)+\delta_{3,1} \Delta P K Y_{t-1}+\delta_{3,2} \Delta P K Y_{t-2}+\delta_{3,3} \Delta A S Y_{t-1}+ \\
& \delta_{3,4} \Delta A S Y_{t-2}+\delta_{3,5} \Delta U T Y_{t-1}+\delta_{3,6} \Delta U T Y_{t-2}+\delta_{3,7} \Delta C D S_{t-1}+\delta_{3,8} \Delta C D S_{t-2}+ \\
& \varepsilon_{1, t}
\end{aligned}
$$

\footnotetext{
5 The ECM/VEC models (such as equations 1-4) are widely used procedures for testing cointegration of several time series. The Johansen test permits more than one cointegrating relationship and is thus more generally applicable than the Engle-Granger test which is based on the test for unit roots in the residuals from a single cointegrating relationship.
} 


$$
\begin{aligned}
& \Delta C D S_{t}=\alpha_{1}+\gamma_{4}\left(E C T_{t}\right)+\delta_{4,1} \Delta P K Y_{t-1}+\delta_{4,2} \Delta P K Y_{t-2}+\delta_{4,3} \Delta A S Y_{t-1}+ \\
& \delta_{4,4} \Delta A S Y_{t-2}+\delta_{4,5} \Delta U T Y_{t-1}+\delta_{4,6} \Delta U T Y_{t-2}+\delta_{4,7} \Delta C D S_{t-1}+\delta_{4,8} \Delta C D S_{t-2}+ \\
& \varepsilon_{1, t}
\end{aligned}
$$

where the four time $(t)$ series variables are defined as below:

- PKY इyield on JPM-EMBI index for Pakistan

- $\quad$ ASY Eyield on JPM-EMBI index for Asia

- UTY =five-year constant-maturity yield on US treasury bonds

- $\quad$ CDS $\equiv$ CDS spread for Pakistan.

The error correction term is:

$$
E C T_{t}=\alpha_{0}+P K Y_{t-1}-\beta_{1} \cdot A S Y_{t-1}-\beta_{2} \cdot U T Y_{t-1}-\beta_{3} \cdot C D S_{t-1}
$$

ECT represents the long-term relationship and the coefficients $\gamma_{i}$ denote the speed of adjustment. The cointegrating equation is:

$$
P K Y_{t-1}=-\alpha_{0}+\beta_{1} \cdot A S Y_{t-1}-\beta_{2} \cdot U T Y_{t-1}-\beta_{3} \cdot C D S_{t-1}
$$

The error correction term in a long-run equilibrium is expected to be zero. However, if the modelled variables deviate from the long-run equilibrium in the last period, the error correction term is nonzero and the returns will adjust to partially restore the equilibrium relation. ${ }^{6}$

The long-term relationship in the ECM is "disturbed" by short-term deviations from the equilibrium. The ECM (equations 1-4) captures the dynamics of the short-term adjustment process. For it to hold, at least one of the $\gamma_{i}$ terms must be significant. If two coefficients $\left(\gamma_{i}\right)$ are significant, this implies that the series influence each other or that there is a feedback relationship between the two. If only one of the error term coefficients $\left(\gamma_{i}\right)$ is significant, it implies that one yield series is driving the other toward longterm equilibrium, but not the other way around. The sign of the error term coefficient $\left(\gamma_{i}\right)$ should be negative for the previous period's positive

\footnotetext{
6 The null hypothesis of no cointegrating equation was rejected for the sample by the log likelihood ratio test (not reported here) and indicated at least one cointegrating equation at a 5 percent significance level, implying that yields exhibit a long-term relationship. We work with first differences, as the series are found to be integrated of the order I(1) in ADF tests.
} 
(negative) deviation to lead to a negative (positive) correction in the current period and drive it toward equilibrium.

The lagged terms of the change in yields, included as independent variables, indicate a short-run dynamic (or statistical cause-and-effect) relationship between the two yields. If the lagged coefficient of $\triangle A S Y$ is significant in the $\triangle \mathrm{PKY}$ regression or if $\triangle \mathrm{ASY}$ significantly affects $\triangle \mathrm{PKY}$, this would suggest that Asian yields affect the Pakistani yields. Similarly, if the lagged coefficient of $\triangle \mathrm{UTY}$ is significant in the $\Delta \mathrm{PKY}$ regression, we can infer that treasury yields affect the Pakistani yields. If neither lagged coefficient is significant, then no inter-exchange "cause-and-effect" relationship can be inferred.

\subsection{Multivariate GARCH Model}

An appropriate approach to modeling the dynamic behavior of yields is to use the expanded GARCH (p, q) model, which is the standard method of incorporating dynamic volatility in financial time series (see Poon \& Granger, 2003). Our preliminary checks on the data reveal that the assumption of constant volatility does not hold. This is consistent with the well-documented phenomenon of volatility clustering, i.e., large changes in asset values are followed by large changes in either direction. This leads us to use a GARCH $(1,1)$ model, the dynamics of which have the following specification:

$X_{t}=\mu_{t}+\sigma_{t} Z_{t}$

Here, the dependent variable $X_{t}$ is the yield on the Pakistan EMBI (PKY). The mean equation $\mu_{t}$ contains three explanatory variables: $A S Y_{t}$, $U T Y_{t}$ and $C D S_{t}$. We run two models, one with the CDS spread for Pakistan and one without, to examine the effect of domestic risk on bond yields. The variance equation is structured as follows:

$\sigma_{t}^{2}=w+\alpha\left(X_{t-1}-\mu_{t-1}\right)^{2}+\beta \sigma_{t-1}^{2}$

with $w, \alpha$ and $\beta>0$ and $(\alpha+\beta)<1$ and where $\sigma_{t}$ is the volatility of the return on day $t$ and $\mu_{t}$ and $X_{t}$ are the expected return and actual yield, respectively. The stochastic variable $Z_{t}$ represents the residuals assumed to be i.i.d. 
The data series spans the period November 2004 to January 2017. This is divided into subperiods, accounting for the special circumstances of the GFC period, as follows:

- Full sample:

$11 / 1 / 2004$ to $1 / 27 / 2017$

- Pre-GFC period:

$11 / 1 / 2004$ to $4 / 2 / 2007$

- GFC period:

$7 / 2 / 2007$ to $6 / 30 / 2009$

- Post-GFC full sample:

$7 / 1 / 2009$ to $1 / 27 / 2017$

- Post-GFC subsample I:

$7 / 1 / 2009$ to $6 / 30 / 2013$

- Post-GFC subsample II:

$7 / 1 / 2013$ to $1 / 27 / 2017$

\section{Results and Discussion}

Tables A2-A3 in the Appendix give the results of the empirical exercise using the cointegration model (VEC/ECM equations 1-5). The results are reported for each period (A-F) as described above. Tables A4-A5 give the results obtained from the GARCH models (equations 6-7) for each period, A-F. In each case, the model is estimated first excluding and then including the CDS spread series. The t-statistics are reported in italics under each coefficient and the statistical significance indicated by asterisks.

\subsection{Cointegration Results}

We focus on the ECM equations in which the Pakistani yield series (PKY) is the dependent variable. The following observations emerge from Tables A2 and A3 (see Appendix). The coefficient ( $\gamma$ ) of the first cointegration equation (PKY) is not significant for the full-period sample $(A=11 / 1 / 2004$ to $1 / 27 / 2017$ ). This is also the case for the full-period sample post-GFC as well as for the GFC period (7/2/2007 to 6/30/2009). This implies that any long-term relationship between the yields is tenuous, although the relationship may hold for subperiods, as indicated by the significant coefficients for subperiod B (pre-GFC) and both post-GFC periods, E and F, subsamples I and II. The instability of a long-run cointegrating relationship is revealed by the shifting signs and magnitudes of the coefficient values for different periods.

This inference is reinforced when we see that, while the coefficients of determination (R-squares) are high (0.30-0.45) for the PKY equations, much of the model's explanatory power lies in the lagged value of the Pakistani yields. However, the international market variables (the Asian and 
US yields and the CDS spreads) seem to play a substantive role in all subperiods excluding the GFC, as indicated by the significant coefficients of the lagged values of these explanatory variables.

A comparison between the last two subsample periods, E $(7 / 1 / 2009$ to $6 / 30 / 2013)$ and $F(7 / 1 / 2013$ to $1 / 27 / 2017)$ should be of significant current interest. For the most recent period $(F)$, the models have higher explanatory power than in the previous period (E). In addition, the coefficients of all the explanatory variables are significant, whereas the coefficients of the US yields and CDS were not significant in the previous period.

It is interesting to note that, in the cointegrating equation, the coefficients of the Asian yields are positive in subsample I (before $7 / 1 / 2013$ ), but negative in subsample II (since 7/1/2013). Over the first period (2009-13), the Asian yields continued to decline due to monetary easing in many developed countries. The Pakistani yields also declined during this period, implying that there was a positive relationship between the two. For the second subsample period (2013-17), we see global interest rates and Asian yields increasing somewhat, as quantitative easing policies were relaxed. However, there is a negative relationship between the Asian and Pakistani yields: the latter appear to have fallen during this period in response to the domestic economic environment, despite a slight increase in international interest rates.

Notwithstanding the apparent improvement in the country's financial conditions, there is still a substantial residual or model risk stemming from exogenous risk factors, which seems to be driving the yields on the Pakistani Eurobonds. These factors could include political and security factors such as the incidence of terrorism. A decline in the price of crude oil could also be a factor, as it would lower the country's default probabilities. It follows that further improvement (i.e., a fall in the bond yields) could be achievable by improving domestic conditions.

The period-to-period variation noted in the values of the estimated parameters is consistent with earlier findings. For example, Comelli (2012) finds that the impact and significance of country-specific and global explanatory variables on bond spreads varies across regions as well as economic periods. In crisis times, good macroeconomic fundamentals are helpful in containing bond spreads, but not as much as in non-crisis times. 
It seems that bond spreads may reflect the impact of extra-economic forces, particularly when a financial crisis occurs. Hall, Anderson and Granger (1992) use cointegration analysis to analyze US treasury bill yields and find that their ECM is unstable over the Federal Reserve's policy regime changes. McGuire and Schrijvers (2003) find that a single common factor explains approximately 80 percent of the common variation in spreads on emerging market bond debt across countries. This factor seems to reflect changes in investors' attitudes toward risk and risk premiums.

\subsection{GARCH Model Results}

The results obtained from the empirical models with GARCH effects (equations 6 and 7) are reported in Tables A4 and A5 (see Appendix). As before, the estimations are carried out for each period (A-F). Two models are run for each period, that is, with and without the CDS spreads on the right-hand side. The tables also report the p-values against each estimated parameter.

We see that the Asian yield (ASY) coefficients are statistically significant for all periods at 1 percent or better levels. Across most periods, the coefficients of the US treasury yields are also significant for the three subperiods - the full-sample period (A) and the post-GFC full-sample period (D) at 1 percent level of significance, and for the pre-GFC period (B) at 5 percent level of significance. This reflects the linkages between Pakistani bond yields and international interest rates. However, for the most recent period, the coefficient of the CDS spreads and the constant term are highly significant. This may be because the assessment of the country's default probabilities as reflected in the CDS spreads is beginning to affect the bond yields in a statistically meaningful manner.

The constant term in the empirical equation captures the average day-to-day change in the yields. 7 The estimated values of the constant terms are -0.0035 and -0.0030 percent for the two post-GFC subperiods (E and F), respectively, which when annualized represent a decrease of -1.27 and 1.10 percent a year for the two periods, respectively. Therefore, the empirical evidence shows a definite downward trend in the yields over the post-GFC period. The rate of decrease was faster in the first period (2009-13) than in the second period (2013-17). This is as expected: at lower levels of yield,

\footnotetext{
7 Note that the models use first differences in yields. The series are not stationary at level: they are integrated of the order I(1) and, therefore, first differences are used.
} 
further declines would be harder to accomplish, i.e., the yields tend to stabilize at lower levels.

As in the case of the ECM models, the explanatory power of the GARCH models is rather weak. The R-squares are in the range of 1-3 percent, except for the most recent period (2013-17) when the R-square statistic is about 8 percent - which is much larger than the 1.3 percent estimated for the previous subperiod (2009-13).

These results have two implications. First, the Pakistani Eurobond yields in this period appear to be more in sync with international yields, indicating that country-specific risk factors have less influence. Second, there is still a large part of risk that is unexplained and originates from countryspecific conditions. Therefore, the key to driving the yields lower lies in ameliorating domestic economic, political and security conditions.

\section{Conclusion and Implications}

This paper examines Pakistan's external debt position, using the marginal cost of external debt as indicated by the yields on the country's Eurobonds and the spreads on the CDS being traded in international markets. We conduct an econometric analysis of the linkages between Pakistani yields and international yields. The market pricing of the Eurobonds and related derivative securities (CDS) provides valuable market signals as to the marginal cost and future sustainability of external debt. The marginal cost of external debt should be the relevant cost component in the weighted average cost used to evaluate capital projects with an FX component.

Our analysis of the yields on Pakistani Eurobonds reveals a sharp decline in these yields from the peak they reached during the GFC. Since then, this declining trend has continued. In the initial post-GFC period, the decline was driven largely by quantitative easing and the resultant low interest rates in international debt markets. However, we note a continued decline in the yields in the more recent period, 2013-17, which seems to indicate that the county's borrowing capacity strengthened over this time. This inference is consistent with what emerges when we examine the country's conventional ratios used to evaluate the sustainability of external debt, such as the debt/GDP ratio and sovereign debt ratings. While the Pakistani yields seem to be converging onto the yields for other Asian countries, the yield spread between Pakistan and other countries is still substantial. 
We should be mindful of two risk factors. First, we have seen the yields spike disproportionately in response to increases in international interest rates during periods of turmoil. Thus, the country seems to be vulnerable to adverse shocks to the financial market. Second, the country's Eurobond yields are not explained well by the financial fundamentals of the international debt market, for example, the Asian bond index yields. This low degree of correlation with international bond yields may be desirable from the perspective of international investors, as it represents portfolio diversification opportunities for them. On the other side of the coin, the low explanatory power of the model based on international market yields indicates that a large part of the total risk is country-specific and is not diversifiable by the country. It is, therefore, important to monitor and manage the risk exposure of external debt. 


\section{References}

Abbasi, Z. (2016). Excessive government borrowing: External financing requirement to increase to $\$ 15 \mathrm{bn}$ : Pasha. Business Recorder, 3 October. Available from http://epaper.brecorder.com

Afonso, A., \& Rault, C. (2010). Long-run determinants of sovereign yields (Working Paper No. 15). Lisbon: Technical University of Lisbon.

Ahmad, E. (2011). A qualitative analysis of Pakistan's external and internal debt. Lahore Journal of Economics, 16, 123-157.

Arslanalp, S., \& Tsuda, T. (2014). Tracking global demand for emerging market sovereign debt (Working Paper No. 14/39). Washington, DC: International Monetary Fund, Monetary and Capital Markets Department.

Atrissi, N., \& Mezher, F. (2011). Sovereign debt crisis and credit default swaps: The case of Greece and other PIIGS. In M. Bellalah \& O. Masood (Eds.), 6th International Finance Conference on Financial Crisis and Governance. Newcastle upon Tyne: Cambridge Scholars Publishing.

Babecký, J., Havránek, T., Matějů, J., ... Vašíček, B. (2012). Banking, debt and currency crises: Early warning indicators for developed countries (Working Paper No. 1485). Frankfurt: European Central Bank.

Bellas, D., Papaioannou, M. G., \& Petrova, I. (2010). Determinants of emerging market sovereign bond spreads: Fundamentals vs. financial stress (Working Paper No. 10/281). Washington, DC: International Monetary Fund, Monetary and Capital Markets Department.

Bokhari, J. (2016). Debt dilemma, accumulating peril. Dawn, 3 October. Available from https://www.dawn.com/news/1287624

Ciarlone, A., \& Trebeschi, G. (2005). Designing an early warning system for debt crises. Emerging Markets Review, 6(4), 376-395.

Comelli, F. (2012). Emerging market sovereign bond spreads: Estimation and back-testing (Working Paper No. 12/212). Washington, DC: International Monetary Fund, Institute for Capacity Development. 
Csonto, B., \& Ivaschenko, I. (2013). Determinants of sovereign bond spreads in emerging markets: Local fundamentals and global factors vs. everchanging misalignments (Working Paper No. 13/164). Washington, DC: International Monetary Fund, European Department.

Di Bella, G. (2008). A stochastic framework for public debt sustainability analysis (Working Paper No. 08/58). Washington, DC: International Monetary Fund.

Engle, R. F., \& Granger, C. W. J. (1987). Cointegration and error correction: Representation, estimation and testing. Econometrica, 55(2), 251276.

Fuertes, A.-M., \& Kalotychou, E. (2007). Optimal design of early warning systems for sovereign debt crises. International Journal of Forecasting, $23,85-100$.

Goktas, O., \& Hepsag, A. (2015). The analysis of external debt sustainability by periodic unit root test with structural break: The case of Turkey. Research in Applied Economics, 7(4), 1-15.

Gurría, A. (2014, November). Emerging trends and challenges in official financing. Closing remarks by the Secretary General, OECD, at the Paris Club Forum. Retrieved from https:/ / www.oecd.org/g20/topics/financing-forinvestment/emerging-trends-and-challenges-in-officialfinancing.htm

Hall, A. D., Anderson, H. M., \& Granger, C. W. J. (1992). A cointegration analysis of treasury bill yields. Review of Economics and Statistics, 74(1), 116-126.

International Monetary Fund. (2013). A new look at the role of sovereign credit default swaps. In Global financial stability report: Old risks, new challenges (chap. 2). Washington, DC: Author.

International Monetary Fund. (2016). Pakistan: Eleventh review under the extended arrangement and request for modification of performance criteria and extension of the extended arrangement - Press release; staff report; and statement by the executive director for Pakistan (Country Report No. 16/207). Washington, DC: Author. 
Iqbal, A., Turabi, Y. R., Hussain, J., \& Laghari, A. (2015). Investigating the role of external trade and external debt on the economic growth of Pakistan. IBT Journal of Business Studies, 11(1), 27-39.

Khan, A. H. (2016). Rising debt: A serious threat to the national security (Working Paper No. 3). Islamabad: National University of Sciences and Technology, School of Social Sciences and Humanities.

Lang, M. (2013). The early warnings of balance-of-payments problems: Kaminsky and Reinhart revisited (Working Paper No. 205). Frankfurt: Frankfurt School of Finance and Management.

Lewis, J. (2011, July). Towards an early warning model of sovereign debt and financial sector crises with an application to the case of Jamaica. Paper presented at the System Dynamics Conference, Washington, DC.

Loser, C. M. (2004). External debt sustainability: Guidelines for low- and middleincome countries (G-24 Discussion Paper No. 26). Geneva: United Nations Conference on Trade and Development.

Mahmood, T., Arby, M. F., \& Sherazi, H. (2014). Debt sustainability: A comparative analysis of SAARC countries. Pakistan Economic and Social Review, 52(1), 15-34.

Manasse, P., Roubini, N., \& Schimmelpfennig, A. (2003). Predicting sovereign debt crisis (Working Paper No. 03/221). Washington, DC: International Monetary Fund.

McGuire, P., \& Schrijvers, M. A. (2003). Common factors in emerging market spreads. BIS Quarterly Review (December), 65-78.

Min, H.-G., Lee, D.-H., Nam, C., Park, M.-C., \& Nam, S.-H. (2003). Determinants of emerging-market bond spreads: Cross-country evidence. Global Finance Journal, 14(3), 271-286.

Muhanji, S., \& Ojah, K. (2011). Management and sustainability of external debt: A focus on the emerging economies of Africa. Review of Development Finance, 1(3-4), 184-206.

Poghosyan, T. (2012). Long-run and short-run determinants of sovereign bond yields in advanced economies (Working Paper No. 12/271). Washington, DC: International Monetary Fund, Fiscal Affairs Department. 
Poon, S.-H., \& Granger, C. W. J. (2003). Forecasting volatility in financial markets: A review. Journal of Economic Literature, 41(2), 478-539.

Rowland, P., \& Torres, J.-L. (2004). Determinants of spread and creditworthiness for emerging market sovereign debt: A panel data study. Bogota: Banco de la República.

Tian, Y., Li, C., \& Lu, L. (2012). Early-warning and risk prevention of sovereign credit rating downgrades: Empirical test from 35 country panel data. Management Science and Engineering, 6(3), 51-55.

Tirmizi, F., \& Masooma, S. (2017). Pakistan's next economic crisis. Pakistan Today, 20 February. Available from http:/ / profit.pakistantoday.com.pk

Waheed, A. (2006). Sustainability and determinants of domestic public debt of Pakistan (Discussion Paper No. 137). Nagoya: Nagoya University, Graduate School of International Development. 
Appendix

Table A1: Summary of listed Eurobonds/sukuk

\begin{tabular}{|c|c|c|c|c|c|c|c|c|c|c|}
\hline & $\begin{array}{l}\text { Issue } \\
\text { year }\end{array}$ & $\begin{array}{l}\text { Bond } \\
\text { type }\end{array}$ & Borrower & Regulation & Market & $\begin{array}{c}\text { Placement } \\
\text { date }\end{array}$ & $\begin{array}{l}\text { Maturity } \\
\text { date }\end{array}$ & Coupon & $\begin{array}{l}\text { Latest } \\
\text { value }\end{array}$ & Amount \\
\hline & & & & & & & & $\%$ & $\%$ & USD \\
\hline 1 & 2006 & Straight & GOP & $144 \mathrm{~A}$ & US & $3 / 30 / 2006$ & $3 / 31 / 2036$ & 7.88 & 96.500 & $300,000,000$ \\
\hline 2 & 2006 & Straight & GOP & $\operatorname{Reg} S$ & Intl & $3 / 30 / 2006$ & $3 / 31 / 2036$ & 7.88 & 96.800 & \\
\hline 3 & 2007 & Straight & GOP & $144 \mathrm{~A}$ & US & $6 / 1 / 2007$ & $6 / 1 / 2017$ & 6.88 & 101.418 & $750,000,000$ \\
\hline 4 & 2007 & Straight & GOP & $\operatorname{Reg} S$ & Intl & $6 / 1 / 2007$ & $6 / 1 / 2017$ & 6.88 & 101.300 & \\
\hline 5 & 2014 & Straight & GOP & $144 \mathrm{~A}$ & US & $4 / 8 / 2014$ & $4 / 15 / 2019$ & 7.25 & 105.750 & $1,000,000,000$ \\
\hline 6 & 2014 & Straight & GOP & $\operatorname{Reg} S$ & Intl & $4 / 8 / 2014$ & $4 / 15 / 2019$ & 7.25 & 105.900 & \\
\hline 7 & 2014 & Straight & GOP & $144 \mathrm{~A}$ & US & $4 / 8 / 2014$ & $4 / 15 / 2024$ & 8.25 & 108.375 & $1,000,000,000$ \\
\hline 8 & 2014 & Straight & GOP & $\operatorname{Reg} \mathrm{S}$ & Intl & $4 / 8 / 2014$ & $4 / 15 / 2024$ & 8.25 & 108.450 & \\
\hline 9 & 2014 & Sukuk & SPV2 & $144 \mathrm{~A}$ & US & $11 / 26 / 2014$ & $12 / 3 / 2019$ & 6.75 & 105.125 & $1,000,000,000$ \\
\hline 10 & 2014 & Sukuk & SPV2 & $\operatorname{Reg} \mathrm{S}$ & Intl & $11 / 26 / 2014$ & $12 / 3 / 2019$ & 6.75 & 106.950 & \\
\hline 11 & 2015 & Straight & GOP & $144 \mathrm{~A}$ & US & $9 / 24 / 2015$ & $9 / 30 / 2025$ & 8.25 & 109.649 & $500,000,000$ \\
\hline \multirow[t]{2}{*}{12} & 2016 & Sukuk & SPV3 & NA & NA & $10 / 5 / 2016$ & $10 / 13 / 2021$ & 5.50 & NA & $1,000,000,000$ \\
\hline & & & & & & & & & Total & $5,550,000,000$ \\
\hline
\end{tabular}

Note: GOP = Government of Pakistan (sovereign), SPV2 = Second Pakistan International Sukuk Company Ltd (agency), SPV3 = Third Pakistan International Sukuk Co Ltd.

Table A2: VEC estimates, periods A-C

\begin{tabular}{|c|c|c|c|c|c|c|c|c|c|c|c|c|c|c|c|c|c|c|c|c|}
\hline \multirow{2}{*}{\begin{tabular}{|l} 
Cointegrating \\
Equation: \\
PAKY(-1)
\end{tabular}} & \multicolumn{7}{|c|}{ A: Full Sample $11 / 1 / 2004$ to $1 / 27 / 2017$} & \multicolumn{7}{|c|}{ B: Pre-GFC Period $11 / 1 / 2004$ to $4 / 2 / 2007$} & \multicolumn{6}{|c|}{ C: GFC Period $7 / 2 / 2007$ to $6 / 30 / 2009$} \\
\hline & 1.0000 & & & & & & & 1.0000 & & & & & & & 1.0000 & & & & & \\
\hline ASIAY(-1) & -91408.37 & & & & & & & 1.01 & & & & & & & 18.43 & & & & & \\
\hline$t$-Stat & -25.91 & & & & & & & 7.82 & & & & & & & 12.79 & & & & & \\
\hline USTY(-1) & 50514.31 & & & & & & & -1.38 & & & & & & & -13.08 & & & & & \\
\hline$t$-Stat & 9.11 & & & & & & & -8.13 & & & & & & & -4.59 & & & & & \\
\hline $\operatorname{CDS}(-1)$ & 21553.33 & & & & & & & -1.67 & & & & & & & -3.94 & & & & & \\
\hline$t$-Stat & 40.54 & & & & & & & -13.76 & & & & & & & -19.52 & & & & & \\
\hline Constant & -0.9641 & & & & & & & 0.0000 & & & & & & & 0.0004 & & & & & \\
\hline \begin{tabular}{|l|} 
Error Correction \\
\end{tabular} & $\Delta(\mathrm{PAKY})$ & $\Delta(\mathrm{ASIAY})$ & & $\Delta($ USTY $)$ & & $\Delta(C \Delta S)$ & & $\Delta($ PAKY) & $\Delta(\mathrm{ASIAY})$ & & $\Delta$ (USTY) & & $\Delta(C \Delta S)$ & & $\Delta$ (PAKY) & $\Delta($ ASIAY $)$ & & $\Delta$ (USTY) & $\Delta(C \Delta S)$ & \\
\hline CE Coefficient & 0.000 & 0.000 & & 0.000 & & 0.000 & & -0.358 & -0.096 & & 0.139 & & 0.468 & & -0.002 & -0.004 & & 0.003 & 0.372 & \\
\hline$t$-Stat & -0.34 & 6.43 & *** & $-3.37 *$ & *** & -36.92 & $* * *$ & $-8.33 * * *$ & -2.83 & $* * *$ & 5.02 & *** & 11.66 & $5 * *$ & -0.42 & -1.61 & & $1.79 * *$ & 17.66 & $5 * * *$ \\
\hline$\Delta(\operatorname{PAKY}(-1))$ & -0.664 & 0.018 & & 0.003 & & 0.166 & & -0.443 & 0.071 & & -0.061 & & -0.262 & & -0.667 & 0.040 & & 0.002 & 0.044 & \\
\hline$t$-Stat & $-39.47^{* * *}$ & 2.40 & $* * *$ & 0.56 & & 2.86 & $* * *$ & $-9.38 * * *$ & 1.91 & ** & -2.01 & $* *$ & -5.93 & $\beta^{* * *}$ & $-16.88 * * *$ & $2.26 *$ & ** & 0.18 & 0.29 & \\
\hline$\Delta($ PAKY(-2)) & -0.334 & 0.010 & & 0.004 & & -0.007 & & -0.229 & 0.080 & & -0.046 & & -0.102 & & -0.333 & 0.022 & & 0.009 & -0.123 & \\
\hline t-Stat & $-19.89^{* * *}$ & 1.29 & & 0.67 & & -0.12 & & $-5.94 * * *$ & 2.62 & $* * *$ & -1.86 & ** & -2.83 & $\beta^{* * *}$ & $-8.44 * * *$ & 1.22 & & 0.76 & -0.82 & \\
\hline$\Delta(\operatorname{ASIAY}(-1))$ & 0.140 & -0.344 & & -0.041 & & -2.942 & & 0.250 & -0.454 & & -0.087 & & -0.304 & & 0.210 & -0.288 & & -0.050 & -3.536 & \\
\hline$t$-Stat & $2.85^{* * *}$ & -15.74 & *** & -2.38 & *** & -17.39 & *** & $4.27^{* * *}$ & -9.82 & $* * *$ & -2.31 & $1^{* *}$ & -5.57 & $7^{* * *}$ & $1.79^{* *}$ & -5.46 * & *** & $-1.45 *$ & -7.90 & *** \\
\hline$\Delta(\operatorname{ASIAY}(-2))$ & -0.039 & -0.212 & & -0.003 & & -2.323 & & 0.268 & -0.216 & & -0.047 & & -0.039 & & -0.110 & -0.259 & & 0.007 & -3.564 & \\
\hline$t$-Stat & -0.89 & -11.01 & $* * *$ & -0.19 & & -15.61 & $* * *$ & $5.06 * * *$ & -5.16 & $* * *$ & -1.38 & & -0.79 & & -1.06 & $-5.54=$ & *** & 0.24 & -8.99 & $9 * * *$ \\
\hline$\Delta($ USTY(-1)) & 0.054 & -0.035 & & -0.648 & & 1.996 & & -0.268 & -0.084 & & -0.510 & & 0.559 & & 0.041 & -0.094 & & -0.643 & 3.409 & \\
\hline$t$-Stat & 1.09 & -1.60 & & -37.47 & *** & 11.68 & *** & $-3.79 * * *$ & -1.51 & & -11.23 & $\beta^{* * *}$ & 8.46 & $5^{* * *}$ & 0.30 & -1.50 & & $-15.80^{* * *}$ & 6.41 & $1 * * *$ \\
\hline$\Delta($ USTY(-2)) & 0.043 & -0.003 & & -0.381 & & 0.805 & & -0.279 & -0.037 & & -0.282 & & 0.186 & & 0.132 & 0.015 & & -0.401 & 1.162 & \\
\hline$t$-Stat & 0.90 & -0.14 & & $-22.89 *$ & *** & 4.90 & $* * *$ & $-4.46^{* * *}$ & -0.75 & & -7.01 & $1^{* * *}$ & 3.18 & $8^{* * *}$ & 0.98 & 0.25 & & $-10.26^{* * *}$ & 2.27 & $7^{* *}$ \\
\hline$\Delta(\mathrm{C} \Delta \mathrm{S}(-1))$ & 0.002 & -0.029 & & 0.007 & & 0.087 & & -0.413 & -0.132 & & 0.144 & & -0.195 & & -0.007 & -0.024 & & 0.007 & 0.212 & \\
\hline$t$-Stat & 0.31 & $-8.11 *$ & *** & $2.57^{*}$ & *** & 3.17 & $* * *$ & $-7.18^{* * *}$ & -2.91 & $* * *$ & 3.88 & $\beta^{* * *}$ & -3.63 & $\beta^{* * *}$ & -0.38 & $-3.05 *$ & *** & $1.37^{*}$ & 3.23 & $3^{* * *}$ \\
\hline$\Delta(C \Delta S(-2))$ & -0.009 & -0.009 & & 0.003 & & 0.123 & & -0.257 & -0.041 & & 0.075 & & -0.198 & & -0.009 & -0.003 & & 0.002 & 0.209 & \\
\hline$t$-Stat & $-1.62 *$ & $-3.74 *$ & *** & $1.54 *$ & & 6.77 & *** & $-6.20^{* * * *}$ & -1.24 & & 2.82 & $2^{* * *}$ & -5.11 & 1 *** & -0.84 & -0.67 & & 0.67 & 4.91 & $1^{* * *}$ \\
\hline Constant & 0.000 & 0.000 & & 0.000 & & 0.000 & & 0.000 & 0.000 & & 0.000 & & 0.000 & & 0.000 & 0.000 & & 0.000 & 0.000 & \\
\hline$t$-Stat & 0.00 & 0.01 & & -0.01 & & 0.01 & & 0.01 & 0.01 & & -0.01 & & 0.01 & & -0.03 & 0.00 & & -0.02 & 0.00 & \\
\hline \# Observations & 3191 & & & & & & & 627 & & & & & & & 588 & & & & & \\
\hline R-squared & 0.338 & 0.208 & & 0.351 & & 0.589 & & 0.435 & 0.247 & & 0.344 & & 0.516 & & 0.352 & 0.201 & & 0.362 & 0.630 & \\
\hline Adj. R-squared & 0.336 & 0.206 & & 0.349 & & 0.587 & & 0.427 & 0.236 & & 0.335 & & 0.509 & & 0.342 & 0.189 & & 0.352 & 0.624 & \\
\hline F-statistic & 180.65 & 93.04 & & 190.96 & & 505.80 & & 52.88 & 22.44 & & 36.00 & & 73.08 & & 34.85 & 16.19 & & 36.38 & 109.31 & \\
\hline
\end{tabular}

Note: ${ }^{* * *},{ }^{* *}, *$ represent significance level at a $\%, 5 \%$ and $10 \%$. 
Table A3: VEC estimates, periods D-F

\begin{tabular}{|c|c|c|c|c|c|c|c|c|c|c|c|c|c|c|c|c|c|c|c|c|}
\hline \multirow{2}{*}{$\begin{array}{l}\text { Cointegrating } \\
\text { Equation: } \\
\text { PAKY(-1) }\end{array}$} & \multicolumn{6}{|c|}{ D: Post GFC Full sample:7/1/2009 to $1 / 27 / 2017$} & \multicolumn{7}{|c|}{ E: Post GFC-sub sample I 7/1/2009 to $6 / 30 / 2013$} & \multicolumn{7}{|c|}{ F: Post GFC-sub sample II $7 / 1 / 2013$ to $1 / 27 / 2017$} \\
\hline & 1.0000 & & & & & & 1.0000 & & & & & & & 1.0000 & & & & & & \\
\hline ASIAY(-1) & -11.63 & & & & & & 14.58 & & & & & & & -2.12 & & & & & & \\
\hline$t$-Stat & -15.86 & & & & & & 6.81 & & & & & & & -16.94 & & & & & & \\
\hline USTY(-1) & 19.94 & & & & & & -42.11 & & & & & & & 1.66 & & & & & & \\
\hline$t$-Stat & 24.55 & & & & & & -18.13 & & & & & & & 11.54 & & & & & & \\
\hline $\operatorname{CDS}(-1)$ & -1.01 & & & & & & 2.12 & & & & & & & 0.41 & & & & & & \\
\hline$t$-Stat & -8.36 & & & & & & 7.29 & & & & & & & 10.28 & & & & & & \\
\hline Constant & -0.0001 & & & & & & 0.0001 & & & & & & & 0.0000 & & & & & & \\
\hline Error Correction & $\Delta(\mathrm{PAKY})$ & $\Delta$ (ASIAY) & & $\Delta$ (USTY) & & $\Delta(\mathrm{C} \Delta \mathrm{S})$ & $\Delta($ PAKY) & $\Delta($ ASIAY $)$ & & $\Delta$ (USTY) & & $\Delta(C \Delta S)$ & & $\Delta$ (PAKY) & $\Delta(\mathrm{ASIAY})$ & & $\Delta($ USTY $)$ & & $\Delta(\mathrm{C} \Delta \mathrm{S})$ & \\
\hline CE Coefficient & -0.003 & 0.025 & & -0.039 & & 0.104 & -0.008 & -0.008 & & 0.021 & & -0.071 & & -0.483 & 0.176 & & -0.092 & & -0.756 & \\
\hline$t$-Stat & -0.67 & $13.83 *$ & *** & $-20.19 *$ & *** & $7.69^{* * *}$ & $-2.28 * *$ & -6.52 & $* * *$ & 17.19 & *** & -6.79 & $* * *$ & $-9.81 * * *$ & 7.88 & *** & $-3.80 *$ & *** & -8.41 & $1^{* * *}$ \\
\hline$\Delta($ PAKY(-1)) & -0.648 & -0.033 & & 0.018 & & -0.015 & -0.612 & -0.019 & & -0.025 & & 0.078 & & -0.408 & -0.122 & & 0.077 & & 0.530 & \\
\hline$t$-Stat & $-30.05^{* * *}$ & $-4.31 *$ & $* * *$ & $2.17 *$ & $* *$ & -0.27 & $-20.48^{* * *}$ & -1.88 & $* *$ & -2.46 & *** & 0.89 & & $-9.61^{* * *}$ & -6.34 & $* * *$ & $3.65 *$ & $* * *$ & 6.83 & $3 * * *$ \\
\hline$\Delta(\operatorname{PAKY}(-2))$ & -0.337 & -0.026 & & -0.001 & & -0.028 & -0.285 & -0.020 & & -0.028 & & 0.042 & & -0.297 & -0.069 & & 0.056 & & 0.188 & \\
\hline$t$-Stat & $-15.83 * * *$ & $-3.37 *$ & $* * *$ & -0.07 & & -0.50 & $-9.67 * * *$ & -2.06 & ** & -2.81 & *** & 0.49 & & $-9.03 * * *$ & -4.64 & *** & $3.45 *$ & $* * *$ & 3.12 & $2^{* * *}$ \\
\hline$\Delta(\operatorname{ASIAY}(-1))$ & 0.212 & -0.409 & & -0.297 & & 0.783 & 0.391 & -0.504 & & -0.148 & & 0.707 & & -0.494 & -0.376 & & -0.236 & & -0.981 & \\
\hline$t$-Stat & $3.06^{* * *}$ & $-16.53 *$ & *** & $-11.43 *$ & *** & $4.26^{* * *}$ & $4.08^{* * *}$ & -15.77 & *** & -4.55 & *** & 2.51 & *** & $-5.11^{* * *}$ & -8.57 & $* * *$ & $-4.94 *$ & *** & -5.55 & $5^{* * *}$ \\
\hline$\Delta(\operatorname{ASIAY}(-2))$ & 0.183 & -0.143 & & -0.136 & & 0.480 & 0.245 & -0.151 & & -0.051 & & 0.599 & & -0.073 & -0.145 & & -0.164 & & -0.386 & \\
\hline$t$-Stat & $3.02^{* * *}$ & $-6.62 *$ & *** & $-5.99 *$ & *** & $2.99 * * *$ & $2.67^{* * *}$ & -4.94 & *** & -1.63 & * & 2.23 & ** & -0.98 & -4.30 & $* * *$ & $-4.48 *$ & *** & -2.85 & $5^{* * *}$ \\
\hline$\Delta($ USTY(-1)) & 0.109 & -0.232 & & -0.152 & & -1.591 & -0.171 & -0.174 & & -0.057 & & -2.264 & & 0.683 & -0.009 & & -0.611 & & 0.916 & \\
\hline$t$-Stat & 1.26 & $-7.52 *$ & *** & -4.69 * & *** & $-6.95 * * *$ & $-1.36 *$ & -4.16 & *** & -1.35 & * & -6.14 & $* * *$ & $7.82 * * *$ & -0.23 & & $-14.17 *$ & *** & 5.73 & $3^{* * *}$ \\
\hline$\Delta($ USTY(-2)) & -0.005 & -0.119 & & -0.109 & & -0.576 & -0.127 & -0.068 & & -0.061 & & -0.780 & & 0.269 & -0.027 & & -0.315 & & 0.511 & \\
\hline$t$-Stat & -0.08 & $-5.33 *$ & $* * *$ & $-4.64 *$ & $* * *$ & $-3.48 * * *$ & $-1.37 *$ & -2.22 & $* *$ & -1.96 & ** & -2.88 & $* * *$ & $3.81 * * *$ & -0.85 & & $-9.06 *$ & $* * *$ & 3.97 & $7 * *$ \\
\hline$\Delta(\mathrm{C} \Delta \mathrm{S}(-1))$ & 0.007 & 0.017 & & -0.027 & & -0.632 & 0.015 & 0.010 & & -0.028 & & -0.580 & & 0.171 & -0.044 & & 0.016 & & -0.625 & \\
\hline$t$-Stat & 0.76 & $5.54 *$ & *** & $-8.32 *$ & *** & $-27.81^{* * *}$ & 1.36 * & 2.81 & *** & -7.64 & *** & -18.08 & $* * *$ & $8.11 * * *$ & -4.65 & *** & $1.57 *$ & * & -16.25 & $5^{* * *}$ \\
\hline$\Delta(\mathrm{C} \Delta \mathrm{S}(-2))$ & -0.005 & 0.007 & & -0.014 & & -0.307 & 0.005 & 0.003 & & -0.016 & & -0.286 & & 0.046 & -0.019 & & 0.007 & & -0.292 & \\
\hline$t$-Stat & -0.65 & $2.29 *$ & ** & $-4.78 *$ & $* * *$ & $-14.38^{* * *}$ & 0.46 & 0.85 & & -4.61 & *** & -9.67 & $* * *$ & $2.64 * * *$ & -2.39 & *** & 0.78 & & -9.22 & $2 * * *$ \\
\hline Constant & 0.000 & 0.000 & & 0.000 & & 0.000 & 0.000 & 0.000 & & 0.000 & & 0.000 & & 0.000 & 0.000 & & 0.000 & & 0.000 & \\
\hline$t$-Stat & 0.04 & 0.02 & & 0.02 & & -0.01 & 0.04 & -0.08 & & 0.00 & & 0.01 & & 0.07 & 0.13 & & 0.05 & & 0.04 & \\
\hline \# Observations & 1977 & & & & & & 1043 & & & & & & & 934 & & & & & & \\
\hline R-squared & 0.324 & 0.358 & & 0.462 & & 0.379 & 0.302 & 0.303 & & 0.479 & & 0.374 & & 0.452 & 0.382 & & 0.407 & & 0.499 & \\
\hline Adj. R-squared & 0.320 & 0.355 & & 0.460 & & 0.376 & 0.296 & 0.297 & & 0.474 & & 0.369 & & 0.447 & 0.376 & & 0.401 & & 0.494 & \\
\hline F-statistic & 104.52 & 121.65 & & 187.92 & & 133.54 & 49.76 & 49.96 & & 105.35 & & 68.71 & & 84.85 & 63.58 & & 70.33 & & 102.21 & \\
\hline
\end{tabular}

Note: ${ }^{* *},{ }^{* *},{ }^{*}$ represent significance level at $1 \%, 5 \%$ and $10 \%$.

Table A4: GARCH model results, periods A-C

\begin{tabular}{|c|c|c|c|c|c|c|c|c|c|c|c|c|c|c|c|c|c|c|}
\hline \multirow{3}{*}{$\begin{array}{c}\text { Dependent } \\
\text { Variable:PAK_Y } \\
\text { Variable }\end{array}$} & \multirow{2}{*}{\multicolumn{6}{|c|}{$\begin{array}{c}\text { A: Full Sample } \mathbf{1 1 / 1 / 2 0 0 4} \text { to } \mathbf{1 / 2 7 / 2 0 1 7} \\
\quad \# \text { observations }=3194\end{array}$}} & & \multirow{2}{*}{\multicolumn{6}{|c|}{$\begin{array}{c}\text { C: GFC Period } 7 / 2 / 2007 \text { to } 6 / 30 / 2009 \\
\text { \# observations }=587\end{array}$}} \\
\hline & & & & & & & & & & & & & & & & & & \\
\hline & Coeff. & z-Stat & Prob. & Coeff. $z$ & z-Stat & Prob. & \multicolumn{6}{|c|}{ 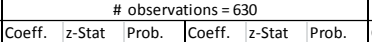 } & Coeff. 2 & z-Stat & \multicolumn{2}{|c|}{ 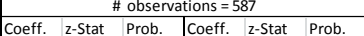 } & z-Stat & Prob. \\
\hline ASIA_Y & 08 & 394 & 0 & 06 & 300 & & 147 & 3.751 & & 88 & 183 & & 474 & 4.164 & 000 & 0.456 & .714 & \\
\hline & & 954 & & 66 & -2.625 & & & & & & 84 & & 97 & 4 & & 96 & 23 & .30 \\
\hline CDS & & & & 05 & 0.736 & 0.46 & & & & -0.049 & -1.478 & 0.139 & & & & 11 & 0.576 & 0.56 \\
\hline \multirow[t]{2}{*}{ Constar } & 000 & -1.120 & 0.2 & 0.000 & -1.074 & 0.28 & 0.000 & 1.488 & 0.4 & 0.000 & 1.319 & 0.18 & 0.000 & $-0.16 /$ & . & 0.000 & -0.162 & 0.8 \\
\hline & \multicolumn{3}{|c|}{ Variance Equation } & \multicolumn{3}{|c|}{ Variance Equation } & \multicolumn{3}{|c|}{ Variance Equation } & \multicolumn{3}{|c|}{ Variance Equation } & \multicolumn{3}{|c|}{ Variance Equation } & \multicolumn{3}{|c|}{ Variance Equation } \\
\hline & 000 & 29.943 & 0.0 & .000 & & & .000 & 2474 & & 0.000 & 24042 & 0.000 & 0.000 & 4641 & 0.000 & 0.000 & 4.792 & 0.00 \\
\hline RESID( & & 45.691 & 0.000 & 063 & 41.450 & 0.000 & 519 & 6.165 & 0.000 & 0.633 & 6.335 & 0.000 & 0.074 & 9.618 & 0.000 & 0.071 & 8.904 & 0.00 \\
\hline $\operatorname{GARCH}(-1)$ & 0.941 & 788.61 & 0.000 & 0.941 & 761.05 & 0.000 & 0.107 & 3.568 & 0.000 & 0.105 & 3.550 & 0.000 & 0.951 & 259.08 & 0.000 & 0.953 & 243.72 & 0.00 \\
\hline Adjust & 0.02 & Akaike & -10.60 & $0.019 \mathrm{~A}$ & aike & -10.60 & 0.0 & aike & -11.74 & $-0.001 A$ & aike & -11.74 & 0.0 & 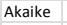 & 9.03 & -0.0 & & -9.0 \\
\hline urbin-Wats & 2.02 & Schwarz & -10.58 & $2.028 \mathrm{~S}$ & Schwarz & -10.58 & $.143 \mathrm{~s}$ & Schwarz & -11.69 & $2.136 \mathrm{~s}$ & Schwarz & -11.69 & $2.079 \mathrm{~s}$ & Schwarz & -8.98 & $2.086 \mathrm{~s}$ & Schwarz & 8. \\
\hline
\end{tabular}

Method: ML-ARCH (Marquardt) - Normal distribution

\section{Table A5: GARCH model results, periods D-F}

\begin{tabular}{|c|c|c|c|c|c|c|c|c|c|c|c|c|c|c|c|c|c|c|}
\hline \multirow{3}{*}{$\begin{array}{c}\begin{array}{c}\text { Dependent } \\
\text { Variable: PAK_Y }\end{array} \\
\text { Variable }\end{array}$} & \multirow{2}{*}{\multicolumn{6}{|c|}{$\begin{array}{l}\text { D: Post GFC Full sample:7/1/2009 to } 1 / \mathbf{2 7} / 2017 \\
\text { \# observations }=1977\end{array}$}} & \multirow{2}{*}{\multicolumn{6}{|c|}{$\begin{array}{l}\text { E: Post GFC-sub sample I 7/1/2009 to 6/30/2013 } \\
\text { \# observations }=1043\end{array}$}} & \multirow{2}{*}{\multicolumn{6}{|c|}{$\begin{array}{l}\text { F: Post GFC-sub sample II 7/1/2013 to } 1 / 27 / 2017 \\
\text { \# observations = } 934\end{array}$}} \\
\hline & & & & & & & & & & & & & & & & & & \\
\hline & \multicolumn{3}{|c|}{\begin{tabular}{lll} 
& \multicolumn{3}{c}{ \# observa } \\
eff. & z-Stat & Prob.
\end{tabular}} & Coeff. & $z$-Stat & Prob. & Coeff. & z-Stat & Prob. & Coeff. & z-Stat & Prob. & Coeff. & $z$-Stat & Prob. & Coeff. & $z$-Stat & Prob. \\
\hline ASIA_Y & 0.595 & 23.756 & 0.000 & 0.594 & 23.740 & 0.000 & 0.324 & 3.305 & 0.001 & 0.322 & 3.292 & 0.001 & 0.725 & $\begin{array}{ll}59.006 \\
\end{array}$ & 0.000 & 0.725 & \begin{tabular}{|l|l|}
5 & 47.002 \\
\end{tabular} & 0.000 \\
\hline UST_Y & -0.150 & -3.541 & 0.000 & -0.150 & -3.528 & 0.000 & -0.111 & -1.190 & 0.234 & -0.110 & -1.172 & 0.241 & -0.001 & $1 \quad-0.031$ & 0.976 & -0.017 & $7 \quad-0.672$ & 0.501 \\
\hline $\operatorname{CDS}$ & & & & 0.008 & 0.835 & 0.404 & & & & 0.007 & 0.436 & 0.663 & & & & 0.026 & 6.929 & 0.000 \\
\hline \multirow[t]{2}{*}{ Constant } & 0.000 & -1.279 & 0.201 & 0.000 & -1.251 & 0.211 & 0.000 & -1.182 & 0.237 & 0.000 & -1.162 & 0.245 & 0.000 & -4.549 & 0.000 & 0.000 & -3.173 & 0.002 \\
\hline & \multicolumn{3}{|c|}{ Variance Equation } & \multicolumn{3}{|c|}{ Variance Equation } & \multicolumn{3}{|c|}{ Variance Equation } & \multicolumn{3}{|c|}{ Variance Equation } & \multicolumn{3}{|c|}{ Variance Equation } & \multicolumn{3}{|c|}{ Variance Equation } \\
\hline Constant & 0.000 & 20.387 & 0.000 & 0.000 & 20.352 & 0.000 & 0.000 & 3.952 & 0.000 & 0.000 & 3.922 & 0.000 & 0.000 & 15.777 & 0.000 & 0.000 & 15.968 & 0.000 \\
\hline $\operatorname{RESID}(-1)^{\wedge} 2$ & 0.058 & 33.358 & 0.000 & 0.058 & 33.251 & 0.000 & 0.020 & 2.770 & 0.006 & 0.020 & 2.764 & 0.006 & 0.771 & 13.737 & 0.000 & 0.818 & $\begin{array}{ll}3 & 13.289\end{array}$ & 0.000 \\
\hline GARCH(-1) & 0.933 & 502.25 & 0.000 & 0.933 & 500.52 & 0.000 & 0.355 & 2.208 & 0.027 & 0.357 & 2.211 & 0.027 & 0.436 & $5 \quad 19.730$ & 0.000 & 0.408 & $\begin{array}{ll}3 & 17.872\end{array}$ & 0.000 \\
\hline Adjusted R-squared & $0.032 A$ & Akaike & -10.82 & 0.032 & Akaike & -10.82 & 0.014 & Akaike & -10.31 & 0.013 & Akaike & -10.31 & 0.083 & 3 Akaike & -11.67 & 0.078 & 3 Akaike & -11.68 \\
\hline Durbin-Watson stat & $1.918 \mathrm{~s}$ & Schwarz & -10.80 & 1.919 & Schwarz & -10.80 & 1.809 & Schwarz & $\begin{array}{l}z-10.28 \\
\end{array}$ & 1.810 & Schwarz & -10.27 & 2.168 & 3 Schwarz & -11.64 & 2.172 & Schwarz & -11.64 \\
\hline
\end{tabular}

Method: ML-ARCH (Marquardt) - Normal distribution 